November 2013

\title{
A Genealogy of Genocide in Francoist Spain
}

Antonio Miguez Macho

Marie Curie Fellow, Contemporary and American History Department, University of Santiago de Compostela

Follow this and additional works at: https://digitalcommons.usf.edu/gsp

\section{Recommended Citation}

Miguez Macho, Antonio (2013) "A Genealogy of Genocide in Francoist Spain," Genocide Studies and Prevention: An International Journal: Vol. 8: Iss. 1: Article 6.

DOI: http://dx.doi.org/10.5038/1911-9933.8.1.4

Available at: https://digitalcommons.usf.edu/gsp/vol8/iss1/6

This Articles is brought to you for free and open access by the Open Access Journals at Digital Commons @ University of South Florida. It has been accepted for inclusion in Genocide Studies and Prevention: An International Journal by an authorized editor of Digital Commons @ University of South Florida. For more information, please contact digitalcommons@usf.edu. 


\title{
A Genealogy of Genocide in Francoist Spain ${ }^{1}$
}

\author{
Antonio Miguez Macho \\ Marie Curie Fellow, Contemporary and American History Department \\ University of Santiago de Compostela
}

\begin{abstract}
Summary: The extermination that was associated with the violence of the Spanish Civil War period and the early 1940s has been studied in depth in recent decades. Until now, however, the concept of genocide has not been discussed with an eye to understanding and interpreting this violence. The hermeneutical and comparative potential of the concept is, however, unquestionable. This article aims both to contextualize the origin and development of the debates about the concept of genocide, and to show what the concept could add to the debate in the case of Spain. In particular, this paper proposes to apply the concept of genocidal practice to the study of the Francoist violence, through analysis of the discourses, the reasons for the violence, and the memories of the events. From this point of view, an analysis will be made of the relationship between the practice of genocidal violence and the discourses of denial devoted to preserving the impunity of the perpetrators to this very day in Spain.
\end{abstract}

Keywords: genocidal practice, Francoist violence, memory, amnesty, impunity, Spain.

Date of peer-review approval: November 20, 2012

\section{The story of Juana and Francisco}

The lifeless body of Juana Capdevielle was found tossed in a ditch along the highway between A Coruña and Madrid, near the village of Rábade in the province of Lugo. The entry in the Office of Vital Statistics makes reference to the discovery of the corpse of an unidentified woman, around 30 years old, with the cause of death given as "gunshots to her chest and head." Among her belongings were a 5-centavo coin, a silver watch, and a ring on the middle finger of her right hand. Those who murdered her were concerned with making it clear that their crime was not an everyday robbery, and they had further taken the opportunity to rape the young woman before executing her. She was a newlywed, and her belongings included the gifts she had received on her wedding day in March 1936. Her deceased husband, Francisco Pérez Carballo, had been the gobernador civil of the province of A Coruña. He was executed in the provincial capital, along with the key personnel of that city's security forces, on the same day he was tried-on July 24-after a sham court-martial of which no written evidence remains. Juana, a librarian and archivist by profession, also was greatly involved in the institutional activity of her partner in those spring days in 1936. For that reason, she was especially detested among the most reactionary media. Both, Francisco and Juana, were killed between July and August 1936. The first crime took place when Galicia had not yet fallen completely into the hands of the leaders of the coup; the second, now in August, was carried out after Juana had been arrested, freed, and finally arrested again, when the front lines of the war were already far from the "tranquil" lands of Galicia, and the insurgents and their backers were in complete control of the situation.

It is one more story among the many that form the jigsaw puzzle of incidents of violence that took place in that context. Indeed, it was a great mosaic that was composed of hundreds, thousands, of personal histories, testimonies, and documents, too, which make it possible to give an account, partial though it may be, of the events experienced in Spain, beginning in July 1936. Undoubtedly, knowledge of the specific cases, including the local or regional point of view as well, influences the perspective we adopt in reflecting on them. All this detail in the knowledge of the individual cases has resulted, on numerous occasions, in a lack of conceptual and comparative thought about their historical significance. In any event, it seems more than appropriate to explicitly discuss the fundamental aspects of a debate so often mentioned, one that in addition is linked with the question of historical memory. ${ }^{2}$

The argument of this article starts from a gamble that is consciously risky and intentionally provocative: to use the perspective of studies on genocide to account for the acts of violence in the area occupied by the insurgents in Spain during the Civil War, which we call "Francoist violence" in an attempt to be concise. First, it is necessary to clarify the meaning of genocide as a heuristic concept and point out its interpretive scope in 
what concerns us here. In addition, these conceptual clarifications are useful for addressing the second point of this article: essentially, to point out both the interpretive and the comparative potential that the concept of genocidal practice can bring to the study of this subject. And third, we will show how the concept of genocide relates to the reconceptualization, in present studies on the "repression," of so-called historical memory, public policies of memory and reparation, and the legal and judicial aspect of it all.

\section{Genocide: One concept and many misunderstandings}

Looking in greater depth at the use and abuse of the concept of genocide, the historian sees, first, formative gaps with respect to its meaning. Paradoxically, there is a lack of awareness that it is a neologism that arose only recently in historical terms (not even seventy years ago) and has found undeniable acceptance not only in academic and legal circles, but also among citizens. Clearly, the everyday use of the concept generally equates its meaning with very serious events of mass killing, and the word is used, above all, to lend force and emphasis. For the same reason, some authors have attempted to label the Francoist violence as "genocide" or have characterized Franco and his associates as "guilty of genocide," with an undisguised aspiration to employ a word far more definitive than the terms they consider more or less neutral, such as "repression" or "oppressors."

It is essential to state that what is written here is by no means intended as denunciation or condemnation: no claim is made that it is more conclusive, or even more definitive. The idea is to employ the concepts with precision, in order to keep politicized attitudes from interfering in the research, and to avoid any trace of "anti-Francoism," an ideology that has been-and continues to be-dominant in a good number of the studies of "repression," encouraged by a certain social perspective that supports it. Breaking away from the discourse of "anti-Francoism" means, in addition, abandoning an alleged and imagined specificity of the Spanish case that eliminates reasonable possibilities for comparison-among other reasons, because the discourse of "anti-Francoism" would become the Spanish version of the "antifascist" discourses in the European setting. Nevertheless, "anti-Francoism," as its name indicates, refers to a purely Spanish phenomenon that is unique and controversial in nature. At the time, there was a prolific controversy, extremely interesting in some aspects, about the "political nature" of the Franco regime, related to the previous question of the authentic nature of the Spanish case, and complicated and shaded by European and international standards for a fascist regime. ${ }^{4}$

One fundamental aspect of this debate has been the strong conceptual differentiation that was established between, on the one hand, the social, political, and ideological foundations of Franco's dictatorship, as well as its effective political practice, and, on the other hand, the enormous violence that accompanied its accession to power. The areas of study seemed airtight, something that is difficult to sustain from the standpoint of rigorous analysis of the facts. The deaths of Francisco and Juana, with which this essay began as examples of many more such deaths, cannot be dissociated from the fascistic, National Catholic, or technocratic policies that characterized Franco's regime. Genocidal violence is not exclusive to one ideology or one particular expression of policy, but rather is one of the mechanisms available to many ideological purposes with an aspiration to reorganize the social sphere. It is, by definition, an ideological violence, because it entails the construction of an enemy in order to destroy that same enemy. But it is a violence that is defined neither by the number of its victims nor by its identitarian character, much less by alleged success or failure in the pursuit of its immediate objectives of annihilation. ${ }^{5}$

The chief difficulty in understanding this use of the term "genocide" derives from the very nature of the concept. By definition, genocide is a practice, not a result. This is precisely why it is not possible to ask whether "genocide existed" in a concrete historical case by thinking in terms of the results of what occurred. It is possible to ask whether there existed a practice of genocide on the basis of what occurred, in itself. The origin of the term goes back specifically to a concern of a pre-emptive sort: to prevent a certain practice from taking place and having devastating consequences for human beings and the societies they make up at the time. Raphael Lemkin, the Polish lawyer and political scientist who coined the word, traces its use to the study of certain historical cases, particularly that of the Armenians, which made an enormous impression on him. Essentially, Lemkin was looking for a definition that would serve in the field of international law to safeguard and protect populations from being subjected to certain types of extreme violence. ${ }^{6}$ It is a search that dates back beyond Lemkin, at least to the mid-nineteenth century, when the development of international humanitarian legislation began.?

Genocide, then, is not a concept invented in light of a single concrete experience, but rather the result of a very long process of defining violence that takes on a new character, at least in the eyes of the person analyzing it. In addition, the concept made possible the sought-after application of international legislation to crimes 
of this kind. That was not achieved after World War I, but would indeed have an effect following the end of World War II. ${ }^{8}$

The path taken by the concept as regards legal matters is well known by scholars who deal with the subject. After gaining international status through the resolution of the United Nations General Assembly in its first sessions in 1946, its meaning subtly changed to apply to legal effects in the Convention on the Prevention and Punishment of the Crime of Genocide in 1948. The specific context in which this definition was approved has been discussed many times, and there is no need to reiterate here the vagueness and absurdity that were introduced from the analytical point of view by the exclusion of political groups. ${ }^{9}$ This has been debated on various levels, including the academic one, because the concept always retained an analytical dimension, which had no need to take into account those kinds of legal agreements. ${ }^{10}$

At this point it must be stated that preference for the concept has to do with the conceptual precision it provides, and that it is not necessarily exclusive, of course. If there were an extraordinary concept making it possible to account for what "genocide" encompasses without losing any shade of meaning thereby, it would be desirable to accept it and make extensive use of it. Thus far, extermination, political violence, repression, persecution, and politicide are concepts that remain faulty in one or more aspects. In this sense, it should be pointed out what exactly the meaning of genocide or "genocidal practice" contributes. The term "genocidal practice" is used in this article to avoid any kind of confusion about its valid legal dimension or about any nuances that the everyday use of the concept could provide:

a. It defines a violent process with the aim of eliminating a social group, based on the use of the government's own machinery and the state's monopoly on theoretically legitimate violence.

b. As such a process, it is placed in a sequence, which necessarily begins with a more or less formal definition of the characteristics of the social group whose elimination is sought, and of who this group's members are. It continues with a number of specific techniques of violence that try to contribute to the aforementioned objective of destroying the social group seen as an adversary, and it is followed by a phase of denial that crimes of such a kind have occurred.

c. The elimination of the social group, which is the aim of a genocidal practice, comes about to a greater or lesser extent through the physical elimination of its members. Nonetheless, it is not limited to this aspect but also involves destruction of the identitarian manifestations that define the group as such from the perspective of the perpetrators.

d. Keeping in mind the involvement of the body politic, which is necessary for such a genocidal practice to be accomplished as such, the whole of the society is concerned in its development, whether from the position of victim or person affected by the measures of repression, or through alignment, actively or passively, with the position of the executioners and persecutors.

\section{Genocidal practice and violence on the home front of Franco's rebels}

The genealogy of the concept is an indispensable preliminary step, so that we can apply the term "genocide" in a discerning way. Nevertheless, the great question is whether it has any interpretive potential for historical analysis of the events that were triggered in Spain as a result of the July 1936 coup détat. In this context, social processes of classification and symbolization were activated, in which the construction of the "Other" as enemy played a fundamental role. ${ }^{11}$ For the perpetrators, the position of these adversaries was determined not by membership in any political organizations in particular but rather by a well-defined identity. This political, social, and cultural identity was not created with the Republic but took decades to form, feeding on common mobilizing experiences as well as experiences of repression. On various occasions, the authority of the Spanish state would act against that very group in the population, which had been identified as opposed to the "social order."

In two revolutionary events in particular-in the general strike of August 1917 and the general strike of October 1934-the machinery of the state had applied extraordinary measures of repression: there were arrests of all the leaders, activists, and individuals seen as tied to the aforementioned group identity. And that happened despite the fact that in the greater part of Spain's territory, the two aforementioned cases of attempted revolution did not turn out to be mere pipe-dreams. In both events, though no crime had specifically been confirmed that would allow the detainees to be charged individually, the soldiers in charge of "restoring public order" identified a group to which they attributed collective responsibility for the occurrences in question. It is not surprising, therefore, that when 1936 arrived the leaders of the coup were so sure about whom they 
ought to go after, because they had spent decades attributing "qualities" to an enemy with whom they already had had to deal. ${ }^{12}$

The first to be convinced of this common identity among the enemies of the "social order," therefore, were their opponents, who interpreted as a negative evil each and every one of the principles of citizenship the others espoused. Thus, the universalization of civil and political rights was regarded as synonymous with the radical egalitarianism that the Bolshevik revolution had enshrined. Further, the promulgation of social rights was seen as the extermination of individual liberty, the limitation of repressive and arbitrary action was regarded as weakness of the state, freedom of conscience as anti-clericalism, women's rights as destruction of the family, encouragement of alternative values as the destruction of traditional society, and recognition of peoples' right to self-government/autonomy as separatism. In the conspiracy theory, which was publicized daily in the conservative media, in shared group meetings, and in everyday conversations, there began a proliferation of ideas such as the hidden power of Freemasons or the influence of Judeo-Bolshevism. ${ }^{13}$

As noted earlier, within the conspiracy theory was included the assignment of a secret nature and calling to the opponents, profoundly destructive in value and with repercussions for civilization. Thus, the perpetrators are assigned the role of defenders not only of their group identity and their more or less private interests, but also of the civilization they would represent together. Historically, this was the idea of "Christianity" or "Western civilization," if not both. The intellectual pedigree of such ideological constructs is rooted in the crises of the Old Regime and in the shaping of the modern liberal nation-states. It takes on a new dimension, however, with the extension of citizen status to increasingly broad sectors of society, something that takes place in the Western world between the end of the nineteenth century and the first decades of the twentieth century. In reality, not only the Jews or the Bolsheviks were the object of these identitarian precautions on the part of broad sectors within modern Western societies; also affected were other groups such as Freemasons and religious, sexual, and cultural dissidents, or even ethnic groups wanting their own national identity. ${ }^{14}$

These processes became part of a phenomenon of dehumanization in the way these groups were characterized: "the most painful question about genocide is, how is it possible for people to kill other people on such a massive scale? The answer seems to be that it is not possible, at least not as long as the potential victims are perceived as people. We have no evidence that genocide was ever performed on a group of equals. Not only must the victims not be equals, but also they must be clearly defined as something less than fully human." ${ }^{15}$ Normally, on this point, more propagandistic arguments are combined with support alleged to be scientific or intellectual in nature. It was not only in the case of the Nazis with the Jews that antisemitic propaganda was reinforced by a racist scientific discourse.

References to the subhuman nature of "the reds" (the republican faction) were made from the very start of the Francoist uprising by the press that supported them, and were spread by the radio stations and repeated in public, political, or religious events and ceremonies. Just look at the identification with worms, animals of a very different kind, or the simile of disease. Ethnic consciousness was understood in this context as a force for preserving the class that sustained and defended the regime instituted by the rebels, which in reality was identified by ideology and, above all, by the will to destroy its enemies. ${ }^{16}$ As a result of this racist conviction, it was believed that the evil of the "reds" was transmitted not only by ideology but also by blood. Hence, a campaign was launched to take away the children of imprisoned mothers, putting them up for adoption by families considered to be "in order." ${ }^{17}$

In the case of Spain, a process of extermination paralleled the gradual taking of territory by the rebels. It was an extermination that was, nevertheless, delimited in time, with the majority of the crimes, whether committed by the method of direct murder or by legalized murder, concentrated in the months after the seizure of each of the territories. In the places that were occupied in the very first days, the cycle of extermination was concentrated in the second half of 1936 and much of 1937. In those places occupied toward the end of the war, most of the victims were executed before the end of $1941 . .^{18}$

Presented below, in Figure 1, is a comparison of the total numbers of victims of violence who were killed in the first three years of violence, taking as a reference the cases of two Spanish regions that experienced different situations and two Latin American countries that experienced genocidal processes in the 1970s.

Developed by the present author on the basis of these data: for Argentina, Inés Izaguirre, "Una larga tradición de prácticas genocidas normalizadas," in Asociación Latinoamericana de Sociología, Latinoamérica en y desde el mundo. Sociología y Ciencias Sociales ante el cambio de época: legitimidades en debate, XXVI Congreso de la Asociación Latinoamericana de Sociología, August 13-18, 2007, Guadalajara, México; for Chile, Patricio Orellana Vargas, "La represión en Chile, 1973-1989," Comisión Nacional de Verdad y Reconciliación, 


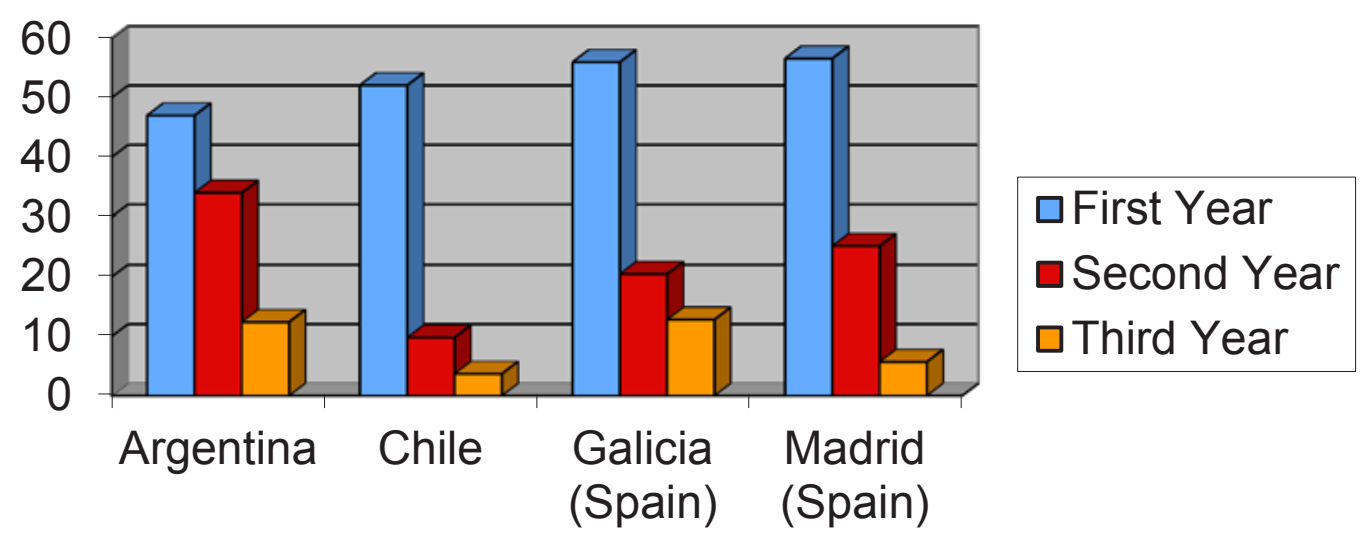

Figure 1. Percentage of the victims killed in the 1st, 2 nd and 3rd year of the violence Argentina (1976-1978), Chile (1973-1975), Galicia (1936-1938) and Madrid (1939-1941).

Informe de la Comisión Nacional de Verdad y Reconciliación, Santiago de Chile, Secretaría de Comunicación y Cultura, no date; for Galicia, L. Fernández Prieto and Proxecto "Nomes e Voces," Informe de Resultados, Santiago de Compostela, USC, 2009; and for Madrid, Julius Ruiz, Repression in Madrid after the Spanish Civil War (New York and Oxford: Oxford University Press, 2005), p. 101.

In the case of Galicia, strictly speaking, no civil war took place; instead, from the first days following the 1936 coup détat, the whole of the territory fell into the hands of the leaders of the coup. Therefore, the violence developed from the first moment on and reached its peak of intensity in the period 1936-1938. In the second Spanish case, Madrid, the dates refer to the time after the end of the Civil War, April 1939, because until then the city had resisted the attacks of the Francoist rebels. In this case, most of the violent deaths were concentrated between 1939 and 1941. If these lines are compared with the cases of Chile and Argentina, it is confirmed that the types of liquidation violence are very similar as to the rates of extermination.

Various explanations have been written to account for this particular criminal chronology. Essentially, these are interim explanations that made the process conditional, but they must be understood within the meaning of genocidal practice. Every genocidal process has a number of phases; extermination is only one of them. The Nazi genocide took place in successive stages, of which the extermination of the Jews meant only a final and late stage. Meanwhile, the stigmatization and persecution of the Jews was preparation for what later would be extermination in the gas chambers, regardless of whether it had already been decided upon or not. ${ }^{19}$

In this regard, there is an important disparity between the linear progressions of the various historical cases of genocide, precisely because genocidal practice depends on the interaction existing among the different social, economic, and cultural forces in a country. In this sense, the case of the Third Reich demonstrates how, in this paradigm of a genocidal regime, the practical implementation of extermination plans was conditioned by the current circumstances. One paradigmatic phenomenon might be the Aktion T4 program, which was put into practice between 1939 and 1941-thus, prior to the bulk of the exterminations of Jews-and was slowed and restrained in large part by protests arising from various sectors of German civil society. In the course of this program, "persons considered incurably ill, children with hereditary defects, or 'unproductive' adults" were exterminated. ${ }^{20}$

One can reflect in that regard about the possible existence of a space that is always present in any society: a space for resistance and for confronting oppression. The concept of totalitarianism, as a synonym for a regime that actually obtains the ability to act with complete impunity, conceals social participation in the genocidal violence, be that participation active or in the form of passive complicity. Tolerance for certain forms of violence practiced under the protection of the state is based on the citizens' acknowledgment of the criminals as authority figures. The importance of Milgram's findings in this regard is well known. ${ }^{21}$ Analysis of the course of the extermination under Franco reveals that the taking of power by the insurgents granted them the status of authorities in practice, despite the extreme illegality of the action by which they attained that power. The same happens in the case of the coups détat in Latin America that triggered practices of extermination. The violence will produce differentiation between victims and executioners, between "the drowned and the saved," until a time has come when anyone who has not been the object of violence on its various scales, ranging from murder to persecution, will become automatically exempt from its consequences. 
The society itself makes sure that difference becomes established, thereby intensifying support for the regime and complicit silence regarding the massacre. ${ }^{22}$

\section{The discourse of denial and impunity}

The last stage of every genocidal practice is always denial of the genocide itself: "the perpetrators of genocides dig up the mass graves, burn the bodies, try to cover up the evidence and intimidate the witnesses. They deny that they committed any crimes, and often blame what happened on the victims." ${ }^{23}$ All the resources that were available to the state apparatus in developing the criminal actions are used subsequently to erase the evidence of what took place, even many decades after the events. Therefore, legal arguments raised to avoid prosecution of this type of criminality are the rule and not the exception. In the Spanish case, continuity of the dictatorial regime was the best guarantee of the predominance of a systematic denial of any genocidal practice. But it was the transition to democracy in the 1970s, known simply as the Transition, and Spanish society as a whole that validated the pattern. To explain this complex way of denying the truth and misrepresenting what was experienced in various social contexts, people turned to developing an entire theory of collective guilt in societies with a genocidal past. ${ }^{24}$

In the genocidal practices, one can detect the construction of the discourse of denial at the moment of crossing from a context of justification to the context of denial. The context of justification serves as preparation for the genocidal practice and fosters its development by seeking to dehumanize the enemy or by appealing to the logic of pillage. But the context of negation directly promotes the objective of concealing the crimes of those responsible, both the perpetrators and the beneficiaries of these crimes. The first stages of transition between the context of justification and the context of denial appear with the progressive marginalization of the violence practiced by groups and militias, which is replaced with more structured military trials.

In the case of Spain, the groups that at the time were paid the warmest tributes are progressively displaced, in some instances becoming the object of persecution and even sent to the European war fronts as part of the División Azul. ${ }^{25}$ In this sense, there is nothing special in the practice of the Franco regime. One can recall what the Nazis did in their time with the SA, as a way of consolidating the power of Hitler and his supporters on the one hand, and on the other as part of a discourse intended to deny the "irregular" nature of the violence practiced by the new regime. The violence practiced in the course of the Russian Revolution has as much to do with a practice intended to eliminate "class enemies" as with the establishment in power of the Bolshevik ruling elite in the society. ${ }^{26}$

Controlling one form of violence in order to continue practicing another form with impunity was also part of the systems employed by the genocidal regimes in Latin America, when the time came to start shutting down channels of irregular violence through "clandestine" mechanisms. If the initial violence of Franco's regime is seen in corpses that appear daily in roadside ditches or in places where all the neighbors can see them, it is progressively changed into something much more secret. In this sense, a network of concentration camps is created, camps that go beyond the temporary detention centers of the early period and, in addition, perform functions of another kind, related to the "re-education" of the prisoners and forced laborers. ${ }^{27}$

On the other hand, the "normalization" of civilian life also starts with putting into operation the logic of revenge and compassion. What until then had been complete indifference to the signs of suffering gives way to acts of mercy toward the families of the victims and toward the survivors. These "displays of clemency" serve in addition to strengthen loyalty to the regime and guarantee complicit silence. Thus, there follow cases at the local level of employers who start rehiring the workers they had dismissed, parish prises who take an interest in their parishioners, and measures that prohibit irregular violence, beatings, or extortion. But beyond this, it becomes state policy with the first sentence reductions in 1943 and what would be large-scale pardons by 1945. Evidently, the international context is an important factor for encouraging these practices and whitewashing Franco's regime. Far beyond this, however, the pardons guarantee social cohesion. What had been at the time violence practiced with aims clearly involving extermination becomes changed into this new discourse of denial in a series of disconnected practices resulting from a context of excesses that frequently conceal personal acts of vengeance. ${ }^{28}$

The context of excesses as part of a logic of revenge is the first discourse of denial that, strictly speaking, is developed within Spanish society with respect to the Francoist practice of extermination. Almost immediately after the crimes occur, publications and flyers appear, giving a detailed account of what happened, pointing in explanation to the criminal nature of the victims as well as to the situation of confusion generated by the absence of authority in the early days. The discourse of denial, then, begins not by forgetting the crimes but by altering 
their significance and diluting their genocidal nature, something that is developed by part of the society itself to differentiate itself from the victims or from those marked by the violence to some extent. Therefore, the public politics of memory has been led, above all, by the actions sponsored by Franco's regime itself. Most interesting of all, without doubt, is the campaign celebrating the "25 years of peace" in the 1960s, because it has a significance that goes far beyond mere justification of the regime and moves on to denial of the genocide. ${ }^{29}$

Starting with the period of the Transition, measures aimed at reparations for "the victims" begin to be established. The sequence begins in 1976 with the awarding of economic compensation to veterans of the Republican faction, or "bando republicano," who were crippled in the Spanish Civil War. Later, in 1979, would come general awarding of social rights and pensions to all the "Republican" combatants and their family members. Interestingly, this same measure includes the voluntary militias that participated in the revolutionary uprising in Asturias in 1934, equating them with the forces of the Spanish Republican Army. Progressive additions meant that in 1984 there was economic compensation in certain cases for members of the "Republican" security forces, and in 1990 for individuals who had been prisoners in Francoist Spain, provided they had spent more than three years in prison.

Besides these kinds of measures, some autonomous regional governments launched initiatives along the same lines, compensating in a different way the "victims and political prisoners of the Franco regime." The economic compensations paid to the victims and family members reflect an attempt to solve the problem that "not all the victims" had been treated equally. The same idea is behind the resolution on condemnation adopted in a unanimous vote by the Congress of Deputies on November 20,2002. The concrete significance of the condemnation is perfectly expressed by historian Ángeles Egido in her fiery defense of the parliamentary declaration: "It was, without doubt, a gigantic step. It was very late in being taken, but finally it was taken, and it is fitting only to be pleased at it, if only because of what the taking of it cost.

There is not the slightest doubt that it can be considered a milestone in the democratic memory of the country and, perhaps, the perfect finishing touch to the transition. In the name of the well-known maxim of [Manuel] Azaña, 'Peace, pity, and pardon,' pressure was put on the local governments to join in the search for people who had disappeared and were buried in mass graves, thus contributing to equal rights for both the victorious families and the vanquished ones when it is time to carry out a simple, and common, act of humanity: to honor their dead with dignity, and publicly"30

In this regard, it may be interesting to analyze a study by the Centro de Investigaciones Sociológicas (CIS; Center for Sociological Research) in October 2005, just before the debate about the "recovery of historical memory" began with more force, propelled by the initiatives of the central government and various autonomous regional governments. The study is revealing because it shows the pulse of Spanish society in the face of a number of questions about the "recognition of the victims of the Civil War." The very posing of the questions is a response to the well-known discourse of mixing war and genocide, partly because reference is made to the "victims of the Civil War" and not to the victims of the violence on the home front, as if there were no distinction to be made. Apart from this, it can be observed that the only points where the consensus is quite broad are reached when it comes to questions referring to the need to guarantee equal treatment "to the victims of the two sides."

But if this is the majority sentiment in Spanish society, the law passed by Parliament in 2007, the Ley de Memoria Histórica, or Historical Memory Law (this time, not unanimously), is even more explicit in this respect. The law's preliminary sections contain two fundamental paragraphs that show how the real reason for the law is to give greater consistency to the denial that is part of the significance of the Transition, because of the obvious burden of political (and moral) blame it holds for a good part of the Spanish left wing. Thus, the first paragraph says, "The spirit of reconciliation and harmony and of respect for pluralism and peaceful defense of all ideas that guided the Transition, enabled the establishment of a Constitution for us, that of 1978, which legally expressed the desire of Spaniards for reunification, forming a social and democratic state under the rule of law with the clear wish for integration." And the final paragraph of this explanation of reasons states: "once and for all, the present Law wishes to contribute to the healing of wounds still open among Spaniards and to give satisfaction to those citizens who suffered, directly or through their relatives, the consequences of the tragedy of the Civil War or the Dictatorship's repression. It wishes to do so in the complete certainty that, by entering more deeply into the spirit of reunification and harmony of the Transition, not only will those citizens be recognized and honored but also the democracy of Spain as a whole. It is not the task of the legislator to implant a particular collective memory. 


\begin{tabular}{|l|c|c|c|c|c|}
\hline & agree & disagree & $\begin{array}{c}\text { either agree } \\
\text { or disagree }\end{array}$ & don't know & no answer \\
\hline $\begin{array}{l}\text { It is useless to debate or take actions to } \\
\text { make amends for incidents that are now past } \\
\text { history. }\end{array}$ & 43.4 & 40.0 & 8.0 & 7.2 & 1.4 \\
\hline $\begin{array}{l}\text { The Civil War victims have been the great } \\
\text { forgotten ones, and now it is time to make } \\
\text { amends for this injustice. }\end{array}$ & 53.3 & 24.0 & 11.2 & 9.9 & 1.6 \\
\hline $\begin{array}{l}\text { There were Civil War Victims on both sides, } \\
\text { and any homage paid to them must include } \\
\text { everyone. }\end{array}$ & 72.9 & 9.9 & 6.3 & 8.8 & 2.1 \\
\hline $\begin{array}{l}\text { The victims were recognized differently, } \\
\text { depending on which side they belonged to. }\end{array}$ & 65.9 & 7.6 & 6.7 & 17.8 & 2.0 \\
\hline
\end{tabular}

Figure 2. Sociological Research Center (Madrid) Study. Questions about the recognition of the victims of the Spanish Civil War (responses in percentages) ${ }^{31}$.

But it is the duty of the legislator and of the law to compensate the victims, to enshrine and protect with maximum legal vigor the right to personal and family memory as an expression of complete democratic citizenship, to nurture constitutional values and to promote the understanding of and reflection on our past in order to avoid the repetition of situations of intolerance and human rights violations such as those experienced then." ${ }^{32}$

Almost one year after the processing of this initiative, on October 30, 2008, the United Nations Commission on Human Rights, a body of independent experts that supervises the implementation of the International Covenant on Civil and Political Rights by the member states, after examining the fifth periodic report presented by Spain, issued, as is usual, its concluding observations. In them, there was praise for what were considered the positive aspects presented in the report, and it was specifically stated that "the Commission welcomes with satisfaction Law No. 52/2007, 'Historical Memory Law', which foresaw compensation for the victims of the dictatorship." Nevertheless, shortly thereafter, it was stated (this time, among the aspects regarded as negative) that "although note has been taken of the recent decision of the National Court of Spain to look into the question of the disappeared, the Commission is concerned by the continuing applicability of the Amnesty Law of 1977."

Next, the Commission reminded the Spanish state of the non-applicability of statutory limitations to crimes against humanity and of the incompatibility of the amnesty laws with the International Covenant on Civil and Political Rights, as well as with other rulings of international law to which Spain subscribed. Finally, the critical comments as a whole were summed up in the following recommendation: "The member state would have to:

a. consider the repeal of the Amnesty Law of 1977;

b. take the legal measures necessary to guarantee recognition of the inability of national courts to apply statutory limitations to crimes against humanity;

c. foresee the creation of a committee of independent experts charged with restoring historical truth about the human rights violations committed during the civil war and the dictatorship; and

d. permit the families to identify and exhume the bodies of the victims and, in this case, pay reparations to the families."33

In October 2008, the UN Commission was unaware of the course that events were going to take with regard to "the recent decision of the National Court" to which it referred with satisfaction. Specifically, this was the famous inquiry opened by the judge Baltasar Garzón, who had decided to use his judicial authority to investigate a number of complaints lodged by private individuals and by various associations involved in recovery of historical memory. In the judicial decree of October 2008, the judge said: "The events described and recounted since July 18,1936 , besides belonging to the category of crimes against humanity, include the crime of illegal detention, without the authorities and persons responsible for contributing to the disappearance of the victims having provided the place or the keys to find the location of the bodies, a situation that persists, in 
the great majority of cases, to the present day. That is, without having given information on the whereabouts of many of the detainees, so that, if the lists were provided and the bodies were found, the crime would cease to be committed.

Therefore, the point of this investigation, among other objectives, is to put an end to the commission of a permanent crime. ${ }^{34}$ And the Commission could express its satisfaction because it perhaps had not examined or could not examine the significance of the fact that the Public Prosecutor's Office (Ministerio Fiscal) had given notice of appeal against the decree by which Garzón declared himself competent. Upon being rejected by the judge himself, ${ }^{35}$ the appeal moved to the next-higher court, the Criminal Chamber of the National Court, which by majority shared the prosecution's opinion. ${ }^{36}$ Before this decision, Judge Garzón had declined jurisdiction, deferring to the territorial courts, and the case had been closed in November. ${ }^{37}$

Later, Baltasar Garzón was accused of breach of legal duty (prevaricación) for having allowed this lawsuit to proceed initially, and his case was taken to court for oral hearings; finally he was acquitted by the Supreme Court of Spain. This acquittal, nevertheless, did not prevent the Supreme Court from describing the "erroneous" proceeding opened by Judge Garzón and making it the ultimate judicial argument for all the principles of denial from which the Spanish process of transition to democracy arose. Proof of that can be observed in the following lines: "the fundamental idea of the 'transition,' so highly praised nationally and internationally, was to obtain a peaceful reconciliation among the Spaniards, and both the Amnesty Law and the Spanish Constitution were extremely important milestones in that historical development.

It must be recalled that the Constitution, which implemented an express repeal of various regulations, in some way mentions among them the Amnesty Law, which is logical, as it was an essential, irreplaceable, and necessary foundation for overcoming Francoism and all that Francoism meant. To pursue a peaceful 'transition' was no easy task, and what doubt is there that the Amnesty Law also represented an important indicator to the various sectors of society, so that they would accept certain steps that would have to be taken in the establishment of the new regime in a peaceful way, avoiding a violent revolution and a return to conflict. It is precisely because the 'transition' was the wish of the Spanish people, articulated in a law, that no judge or court, in any way, can question the legitimacy of such a process. This is a valid law, whose possible repeal would be exclusively the responsibility of the Parliament." ${ }^{38}$

\section{Epilogue: Neither justice nor history}

Historically, societies exposed to their sins have required state-sponsored acts of contrition. In various cases in Latin America, the new democratic regimes after the end of the genocidal dictatorships hastened to create a number of "truth commissions," where the victims and survivors of the violence gave testimony. Certainly, the course taken by the events following those incidents differs from one country to another, especially with respect to the legal prosecution of the executioners, but the commissions, like the acts of contrition, were a preliminary and necessary step to combat the prevailing discourse of denial and to make it possible to fight against impunity. Little wonder, Julio Cortázar pointed out, that there was the added problem of the genocides in which the perpetrators were fellow countrymen of the victims: "When disappearance and torture are handled by people who talk like us, have the same names as ours and have gone to the same schools, share customs and gestures, come from the same soil and the same history, the abyss that opens in our own mind and in our heart is infinitely deeper than any word that attempts to describe it." ${ }^{39}$

The principal questions posed in this article have to do with the apparent contradictions between the prevailing discourse about the violence, the Francoist dictatorship, or the political transition to democracy in Spain, on the one hand, and the reality of the historical facts and Spain's present, on the other. The responses to the arguments presented here rely on the discourse of denial upon which Spanish democracy is built. It is a discourse with which reference is made to various aspects of the ideal identity with which the Spanish state wishes to identify its own history and its present, and which it communicates through all the resources of broadcasting, education, and propaganda available to it. That denialist discourse also includes the individual or collective contributions of Spanish society. The harmony between the official discourse and the majority social discourse is quite remarkable, at least to the present day.

As part of that discourse of denial in Spanish democracy, an essential spot is occupied by the paradox of transforming the state itself into the defender of democracy elsewhere in the world. One of the bluntest expressions of these kinds of interventions dates back to 1983, when the Spanish Senate created a "Special Commission for Investigation of the Disappearance of Spanish Subjects in the Americas," which issued a finding describing the principal characteristics of the "repression" and energetically condemning the denial of 
the right to investigate the facts by the government of the Argentine dictatorship. It was a report that was even repeated in its main conclusions in 1997, without making any allusion to the obvious comparison with what occurred in Spain, with respect to the people who disappeared and were killed and the crimes of the Franco regime in general. ${ }^{40}$ Thus, the authorization by the principal Spanish courts of the universal principle of justice inspired by the National Court through the persons of Carlos Castresana and Baltasar Garzón did not arise at any time from deep awareness of the implications of that principle for the case of Spain, but from its simple utilization as one more sign of the vitality of Spanish democracy.

The Spanish case does not stand out because of the kind of violence employed or because of the existence of a later denial that that violence had taken place or had possessed particular characteristics. Nor is it the war that makes Spain into a different scenario of its own, because the rationale of the conflict and of the victims by the two sides probably is not a Spanish innovation in its justification or understanding of these kinds of crimes. It is the analysis of the facts and the almost uniform public discourse that are noteworthy, something that responds to an unmistakable wish of Spanish society not to confront its worst fears directly.

This attitude can be justified in political terms as an exercise in mutual concession or by invoking the success of the Transition process, but one must not ignore the direct consequences of what is implied by the fact that the executioners remain unpunished. The body of the acting gobernador civil of the province of $\mathrm{A}$ Coruña in 1936 continues to occupy an anonymous grave in the cemetery of San Amaro in A Coruña, almost as if his memory were aware of being a discomfort rather than a cause for democratic cohesion. When they buried him, his gravediggers left a record in writing that this was now the "ex-gobernador civil." The body of his wife lies anonymously in a cemetery in the province of Lugo, with no more mention than a note made in the civil registry seventy years ago by her executioners themselves. But beyond that, from a historiographical rather than legal point of view, we completely lack the desire to inquire who their executioners were, what persons benefited from those deaths, who denounced those who became victims, and what path they followed later on. The question continues to be the same: Is Spanish society prepared to admit its active participation in a genocidal practice against its own people?

\section{End Notes}

1. This study is done in the context of the projects "Perpetrators, Ordinary People, and Violence during the Spanish Civil War (1936-1939): The Case of Galicia" and "Mecanismos de adaptación social en contextos de violencia estatal masiva. El caso de Galicia (1936-1939) en perspectiva comparada," both, with Antonio Miguez Macho as lead researcher, included in the "Grupo de Referencia Competitiva: Historia agraria e política do mundo rural. Séculos XIX e XX," lead researcher, Lourenzo Fernández Prieto. I am grateful to Dr. Daniel Feierstein and the members of the Centro de Estudios sobre Genocidio at the Universidad Nacional de Tres de Febrero (in Buenos Aires, Argentina) for suggestions regarding the ideas contained in this text.

2. By way of introduction, see Ignacio Peiró, "La consagración de la memoria: una mirada panorámica a la historiografía contemporánea," in Ayer, 53, 2004, pp. 179-205; Jeffrey C. Alexander, “Toward a Theory of Cultural Trauma," in Jeffrey C. Alexander (ed.), Cultural Trauma and Collective Identity (Berkeley: University of California Press, 2004), pp. 1-30; Enzo Traverso, El pasado: instrucciones de uso. Historia, memoria, política (Madrid: Marcial Pons, 2007); Katharine Hodgkin and Susannah Radstone (eds.), Contested Pasts. The Politics of Memory (London: Routledge, 2002); Alberto Rosa, Guglielmo Bellelli, and David Bakhurst (eds.), Memoria colectiva e identidad nacional (Madrid: Biblioteca Nueva, 2000); Julio Aróstegui, "Traumas colectivos y memorias generacionales: el caso de la guerra civil," in Julio Aróstegui and François Godicheau (eds.), Guerra Civil. Mito y memoria (Madrid: Marcial Pons, 2006), pp. 57-94.

3. There are possible examples of this in Francisco Moreno Gómez, 1936: el genocidio franquista en Córdoba (Barcelona: Crítica, 2008), and Fòrum per la Memòria del País Valencià, El genocidio franquista en Valencia. Las fosas silenciadas del cementerio (Barcelona: Icaria, 2008).

4. It is imposible to cite here what has been a true historiographical flood of references, so only the seminal one will be noted: Ismael Saz, Fascismo y franquismo (Valencia: Universitat de València, 2004).

5. Along the lines of what is noted by Daniel Feierstein, El genocidio como práctica social. Entre el nazismo y la experiencia argentina (Buenos Aires: Fondo de Cultura Económica, 2007).

6. With respect to Lemkin, see William Korey, "Raphael Lemkin 'the unofficial man," Midstream, 35: 5 (1989), pp. 45-48. The concept of genocide is presented in Raphael Lemkin, Axis Rule in Occupied Europe: Laws of Occupation -Analysis of Government - Proposals for Redress (Washington, D.C.: Carnegie Endowment of International Peace, 1944).

7. There is a short review of the questions in Xavier Pons Rafols, "Revisitando a Martens: las normas básicas de humanidad en la Comisión de Derechos Humanos," in Marina Vargas Gómez-Urrutia and Ana Salinas de Frías (eds.), Soberanía del Estado y derecho internacional: homenaje al profesor Juan Antonio Carrillo Salcedo, vol. 2 (Seville: Universidad de Sevilla, 2005), pp. 1095-1118. On various aspects of the development of international humanitarian law, see Christopher J. Greenwood, "Historical Development and Legal Basis," in Dieter Fleck (ed.), The Handbook of Humanitarian Law in Armed Conflicts 
(New York: Oxford University Press, 1995), p. 28; also, Antonio Cassese, “The Martens Clause: Half a Loaf or Simply Pie in the Sky?” European Journal of International Law, 11, 2000, pp. 187-216.

8. Daniel Marc Segesser and Myriam Gessler, "Raphael Lemkin and the International Debate on the Punishment of War Crimes (1919-1948)," in Dominik J. Schaller and Jürgen Zimmerer (eds.), The Origins of Genocide. Raphael Lemkin as a historian of mass violence (London/New York: Routledge, 2009), pp. 9-24.

9. William A. Schabas, Genocide in International Law (New York: Cambridge University Press, 2000), p. 135ff.

10. See, among others, Leo Kuper, Genocide: Its Political Use in the Twentieth Century (New Haven: Yale University Press, 1981); Feierstein, El genocidio como práctica social; or Ben Kiernan, Blood and Soil: A World History of Genocide and Extermination from Sparta to Darfur (New Haven: Yale University Press, 2007).

11. See, for example, the studies by Xosé Manuel Núñez Seixas, ¡Fuera el invasor! Nacionalismos y movilización bélica en la Guerra Civil española, 1936-1939 (Madrid: Marcial Pons, 2006) or Francisco Sevillano, Rojos. La representación del enemigo en la Guerra Civil (Madrid: Alianza Editorial, 2007). An original way of approaching this extreme is found in the work of the photographer Sofía Moro, which is a collection of photos and testimonies of protagonists in the Spanish Civil War who happened to meet in time and in space but recount the events from very different points of view: Sofía Moro, Ellos y nosotros (Barcelona: Blume, 2006).

12. Antonio Miguez Macho, "La destrucción de la ciudadanía y la reruralización ideológica de la sociedad. Práctica genocida, perpetradores y víctimas en el caso gallego durante la guerra civil," in Carlos Navajas Zubeldía and Diego Iturriaga Barco (eds.), Actas del II Congreso Internacional de Historia de Nuestro Tiempo (Logroño: Universidad de la Rioja, 2010), pp. 295-308. A recent view of these issues is found in Paul Preston, El holocausto español. Odio y exterminio en la Guerra Civil y después (Barcelona: Debate, 2011).

13. A good summary of the relevance of the atrributions of meaning is in Ángeles Egido León (coord.), Memoria de la Segunda República: mito y realidad (Madrid: Biblioteca Nueva e Centro de Investigación y Estudios Republicanos, 2006), especially in the chapter by Gabriel Jackson on the specter of communism and in the chapter by José Antonio Ferrer on the "Judeo-Masonic conspiracy." The importance of the political discourses of the far right in Acción Española for the formation of conservative opinión on these topics is discussed in Paloma González Cuevas, Acción Española. Teología política y nacionalismo autoritario en España (1913-1936) (Madrid: Tecnos, 1998), and José Luis Rodríguez, La extrema derecha española en el siglo XX (Madrid: Alianza, 1997). In the case of Germany, the face of Nazism is synthetically defined on the basis of the rejection of the Weimar Republic in Robert Gellatelly, No sólo Hitler. La Alemania nazi entre la coacción y el consenso (Barcelona: Crítica, 2002), pp. 23-53.

14. Michel Foucault, Genealogía del Racismo (Buenos Aires: Altamira, 1996). See also Michel Wieviorka, El espacio del racismo (Barcelona: Paidós, 1992).

15. Frank Chalk and Kurt Jonassohn, The History and Sociology of Genocide: Analysis and Case Studies (New Haven: Yale University Press, 1990), p. 28.

16. These are the theories espoused by Colonel Antonio Vallejo Nájera, chief of the military psychiatric services under Franco: Antonio Vallejo Nájera, Eugenesia de la Hispanidad y regeneración de la raza (Burgos: Editorial Española, 1937). On the relationship between these practices and the experiments performed by the Nazis, see Michael Edwards, A Time of Silence. Civil War and the Culture of Repression in Franco's Spain. 1936-1945 (Cambridge: Cambridge University Press, 1998).

17. The issue of handing the children of "reds" for adoption came to public attention as a result of the documentary by Montserrat Armengou and Ricard Bellis, "Els Nens perduts del franquisme," aired in February 2002 by TV3, the Catalan public televisión network. A book on the same topic as the documentary was published: Richard Vinyes, Montserrat Armengou, and Ricard Bellis, Los niños perdidos del franquismo (Barcelona: Plaza \& Janés, 2002). See also Miguel Ángel Rodríguez Arias, El caso de los «niños perdidos» del franquismo: crimen contra la humanidad (Valencia: Tirant lo Blanch, 2008), which supports part of the reasoning present in the decree of the judge at the Audiencia Nacional (National Court, Spain's central criminal court): Baltasar Garzón, Auto de 18 de noviembre de 2008, Sumario (proc. ordinario) 53/2008, "Delitos contra Altos Organismos de la Nación y delito permanente de detención ilegal, sin dar razón del paradero, en el contexto de crímenes contra la Humanidad."

18. In the Spanish case, the studies by Francisco Espinosa have used this sequence of extermination in a systematic way: Francisco Espinosa, "Julio de 1936. Golpe militar y plan de exterminio," in Julián Casanova (coord.), Morir, matar, sobrevivir. La violencia en la dictadura de Franco (Barcelona: Crítica, 2002), pp. 53-119, and Francisco Espinosa and Francisco Sevillano, Exterminio. El terror con Franco (Madrid: Oberon, 2005).

19. There has been an academic debate between two schools of interpretation regarding the place of genocide in the Nazi regime, called "intentionalists" and "functionalists," as summarized in the article by Timothy W. Mason, "Intention and Explanation: A Current Controversy about the Interpretation of National Socialism," in Gerhard Hirschfeld and Lothar Kettenacker (eds.), Der 'Führerstaat': Mythos und Realitat (Stuttgart: Klett-Cotta, 1981), pp. 23-40. The intentionalists believe in the existence of an extermination plan drawn up before the Nazis came to power, based on antisemitic ideology; for example, Lucy Dawidowicz, The Holocaust and the Historians (Cambridge, Mass.: Harvard University Press, 1981). The functionalists see the genocide as an instrument of affirmation in the exercise of power by the Nazis, and as having strongly utilitarian content: Martin Broszat, The Hitler State: The Foundation and Development of the Internal Structure of the Third Reich (London: Longman, 1981) and Hans Mommsen, From Weimar to Auschwitz: Essays in German History (Oxford: Polity Press, 1990).

20. Henry Friedlander, The Origins of Nazi Genocide: From Euthanasia to the Final Solution (Chapel Hill: University of North Carolina Press, 1977); Giovanni de Martis, "El exterminio de discapacitados a manos de los nazis como preludio del Holocausto," in Simhon Samuels, Mark Weitzman, and Sergio Widder (eds.), Antisemitismo: el odio genérico (Buenos Aires: Lilmod, 2009). 
21. Stanley Milgram, Obediencia a la autoridad: un punto de vista experimental (Bilbao: Desclée de Brouwer, D.L. 1998 [1974]), and Thomas Blass (ed.), Obedience to Authority: Current Perspectives on the Milgram Paradigm (Mahwah, N.J.: Lawrence Erlbaum Associates, 2000).

22. Daniel Feierstein, “Guerra, genocidio, violencia política y sistema concentracionario en América Latina," in Daniel Feierstein (coord.), Terrorismo de Estado y genocidio en América Latina (Buenos Aires: Prometeo, 2009), pp. 9-32.

23. Gregory H. Stanton, Ocho estadios del genocidio (New Haven: Yale University Centre for International and Area Studies, 1998).

24. The case of Nazi Germany has been, as in other aspects, the most prolific in this regard. See Javier Moreno Luzón, "El debate Goldhagen: los historiadores, el Holocausto y la identidad nacional alemana," Historia y política: Ideas, procesos y movimientos sociales 1 (1999), pp. 135-162; Federico Finahelstein (ed.), Los Alemanes, el Holocausto y la Culpa Colectiva. El Debate Goldhagen (Buenos Aires: Eudeba, 1999).

25. A unit of Spanish soldiers that served in combat in the East along with the Wehrmacht: Xosé Manuel Núñez Seixas, "Los vencedores vencidos: la peculiar memoria de la División Azul, 1945-2005," Pasado y memoria: revista de historia contemporánea, 4, 2005, pp. 83-113.

26. "The Russian civil war was also a civil war between Reds and Green, a war between the Bolsheviks and their socialist opponents led by the pro-peasant Socialist Revolutionary Party, beginning in May 1918 and finally ending in June 1922 when the leaders of that party were tried," Geoffrey R. Swain, The Origins of the Russian Civil War (London: Longman, 1996), p. 2.

27. See Javier Rodrigo, Cautivos. Campos de concentración en la España franquista, 1936-1947 (Barcelona: Crítica, 2005).

28. In this regard, see Martin Shaw, What is Genocide? (Cambridge: Polity Press, 2007). The different types of logics in the genocidal practices have been analysed in Antonio Miguez Macho, Xenocidio e represión franquista en Galicia (Santiago de Compostela: Lóstrego, 2009).

29. The evolution of the policies of memory during the Franco regime have been masterfully analyzed by Paloma Aguilar Fernández, Memoria y olvido de la Guerra Civil española (Madrid: Alianza, 1996).

30. Ángeles Egido León, “La historia y la gestión de la memoria. Apuntes para un balance," Hispania Nova, 6, 2006.

31. "Estudio CIS no 2622. Barómetro de octubre de 2005," Centro de Investigaciones Sociológicas, Madrid, 2005.

32. "Ley 52/2007, de 26 de diciembre, por la que se reconocen y amplían derechos y se establecen medidas en favor de quienes padecieron persecución o violencia durante la guerra civil y la dictadura," BOE, No. 310, December 27, 2007, pp. 5341053416, specifically pp. 53410 and 53411.

33. UN Commission on Human Rights, "Observaciones finales al Quinto Informe Periódico de España (CCPR/C/ESP/5)," 94th session, Geneva, October 30, 2008.

34. Baltasar Garzón Real, "Auto de 16 de octubre de 2008," Diligencias Previas Proc. Abreviado 399/2006 V, Madrid, October 16, 2008.

35. For the public prosecutor's appeal, see Javier-Alberto Zaragoza Aguado, Chief Prosecutor of the Audiencia Nacional, "Recurso interpuesto al Auto de 16 de octubre de 2008," October 20, 2008, and the rejection of the appeal, Baltasar Garzón Real,"Auto en que se rechaza admitir a trámite el recurso de la Fiscalía," Madrid, October 23, 2008, Sumario (Proc. Ordinario) $53 / 2008$ E Memoria Histórica.

36. The Decree of the Crminal Chamber of the National Court declaring the lack of objective competence of Judge Baltazar Garzón in the case of the victims of Francoism: Audiencia Nacional. Sala de lo Penal. Pleno, "Procedimiento ordinario número 53/08 del Juzgado Central de Instrucción número 5. Expediente número 34/08. Cuestión de competencia del artículo 23 LECR," Madrid, December 2, 2008.

37. Baltasar Garzón Real, Auto de 18 de noviembre de 2008, Sumario (proc.ordinario) 53/2008, "delitos contra Altos Organismos de la Nación y delito permanente de detención ilegal, sin dar razón del paradero, en el contexto de crímenes contra la Humanidad."

38. Supreme Court. Criminal Chamber, "Sentencia 101/2012. Causa especial 20048/2009. Prevaricación judicial. Los denominados 'juicios de la verdad.' Intepretación errónea del Derecho e injusticia," Madrid, February 27, 2012, pp. 20-21. The disbarment of the judge was finally agreed on, for a reseaon unrelated to this matter.

39. Julio Cortázar, "Negación del olvido," in Julio Cortázar, Argentina: años de alambradas culturales (Barcelona: Muchnik, 1984), p. 20.

40. Ministerio de la Presidencia, "Informe oficial sobre los desaparecidos españoles en Argentina," February 20, 1997. 